\title{
PENGEMBANGAN SUMBER DAYA MANUSIA PADA PERPUSTAKAAN UNIVERSITAS HASANUDDIN
}

\author{
Human Resources Development in Hasanuddin University Library \\ Hasyim Mangundjungi ${ }^{1}$, Imran Ismail $^{2}$, Uddin B Sore ${ }^{2}$ \\ ${ }^{1}$ Perpustakaan Universitas Hasanuddin \\ ${ }^{2}$ Program Studi Ilmu Administrasi Negara, Program Pascasarjana, Universitas Bosowa \\ Email: hasyimmangundjungi@gmail.com \\ Diterima: 18 September 2021 \\ Dipublikasikan: 20 Desember 2021
}

\begin{abstract}
ABSTRAK
Penelitian ini dilakukan di Perpustakaan Universitas Hasanuddin yang dilaksanakan pada bulan Februari-Maret 2021. Pendekatan dalam penelitian ini menggunakan deskriptif kualitatif. Teknik pengumpulan data melalui observasi, wawancara mendalam, dan studi kepustakaan. Tujuan dari penelitian ini adalah: (1) Untuk mengetahui sistem pengembangan SDM kepustakawanan terhadap pelayanan di Universitas Hasanuddin; dan 2) Untuk mengetahui hambatan yang dialami dalam pengembangan pustakawan di perpustakaan Universitas Hasanuddin. Hasil penelitian menunjukkan bahwa: (1) Sistem pengembangan kepustakawanan di perpustakaan Universitas Hasanuddin dilakukan melalui berbagai macam kegiatan. Untuk mengembangkan SDM pustakawanan melalui pendidikan dan pelatihan (diklat) dilakukan dengan berbagai bentuk kegiatan, seperti seminar, webinar, workshop atau sharing knowledge (diskusi kecil), uji kompetensi, dan sertifikasi. Sementara itu kegiatan non diklat dilakukan dalam bentuk rotasi pegawai di lingkungan perpustakaan. Untuk tugas belajar belum dilakukan secara langsung melalui inisiatif kelembagaan perpustakaan, karena itu selama ini dilakukan secara mandiri. Untuk promosi jabatan belum dilakukan sesuai dengan yang diatur didalam Menpan RB Nomor 9 Tahun 2014 tentang Jabatan Fungsional Pustakawan dan Angka Kreditnya. (2) Hambatan dalam pengembangan SDM kepustakawanan di perpustakaan Universitas Hasanuddin secara internal berkaitan dengan sikap dan etos kerja para pustakawan yang cenderung abai dan tidak peduli dalam upaya mengembangakan keterampilan yang dimilikinya. Sementara berkaitan dengan hambatan secara eksternal dimana masih banyak pustakawan yang ada di perpustakaan Universitas Hasanuddin yang tidak dapat mengoperasikan layanan secara elektronik berbasis digitalisasi.
\end{abstract}

Kata Kunci: Pustakawan, Sumber Daya Manusia, e-Library.

\begin{abstract}
This research was conducted at the Hasanuddin University Library which was held in February-March 2021. The approach in this study used descriptive qualitative. Data collection techniques through observation, in-depth interviews, and literature study. The aims of this research are: (1) To find out the librarian HR development system for services at Hasanuddin University; and 2) To find out the obstacles experienced in the development of librarians at the Hasanuddin University library. The results of the research show that: (1) The librarianship development system in the Hasanuddin University library is carried out through various activities. To develop human resources for librarians through education and training, various activities are carried out, such as seminars, webinars, workshops or knowledge sharing (small discussions), competency tests, and certifications. Meanwhile, non-training activities are carried out in the form of employee rotation in the library environment. The learning task has not been carried out directly through the library institutional initiative, because so far it has been carried out independently. The promotion of positions has not been carried out in accordance with the provisions of the Minister of Administrative and Bureaucratic Reform Number 9 of 2014 concerning the Functional Positions of Librarians and their Credit Scores. (2) Barriers to the development of human resources for librarianship at the Hasanuddin University library are internally related to the attitudes and work ethic of librarians who tend to be ignorant and do not care about developing their skills. Meanwhile, it is related to external obstacles where there are still many librarians in the Hasanuddin University library who cannot operate digitalization-based electronic services.
\end{abstract}

Keywords: Librarian, Human Resources, e-Library.

This work is licensed under Creative Commons Attribution License 4.0 CC-BY International license

\section{PENDAHULUAN}

Perpustakaan merupakan salah satu pilar yang menyokong berdirinya suatu lembaga pendidikan, termasuk juga pada perguruan tinggi. Kehadiran dan peranan perpustakaan dinilai cukup memberikan pengaruh terhadap kelangsungan hidup perguruan tinggi. Sumber informasi, pusat terselenggaranya penyediaan bahan pustaka, tempat belajar dan berekreasi, semuanya berada di perpustakaan.

Seiring dengan kehadiran teknologi informasi di era digitalisasi sekarang ini, menunjukkan ilmu pengetahuan telah mengalami perkembangan yang demikian pesatnya. Di samping itu, masyarakat pengguna yang dilayani perpustakaan telah berkembang pula menjadi masyarakat 
informasi yang makin adaptif dengan teknologi informasi, lebih kritis, bersikap pro-aktif, dan cenderung menginginkan segala informasi dengan seketika.

Kenyataan ini membawa implikasi dan menuntut perubahan yang besar terhadap peran sumber daya manusia perpustakaan sebagai pekerja informasi dalam kemampuan mengelola dan menyajikan kembali informasi, terutama di lingkungan perpustakaan perguruan tinggi. Untuk menghadapi tantangan tersebut, baik dari perkembangan ilmu dan masyarakat yang dilayani, mau tidak mau sumber daya manusia di perpustakaan perguruan tinggi harus berubah dan mengikuti perkembangan tersebut agar perpustakaan tidak ketinggalan atau ditinggalkan.

Untuk itu, sumber daya manusia yang berkualitas di perpustakaan merupakan suatu keharusan dan tuntutan utama yang perlu diperhatikan dan ditingkatkan yaitu dengan cara memperbarui terus menerus pengetahuan, keterampilan, dan sikap kerja para stafnya melalui kegiatan atau program-program pengembangan sumber daya manusia.

Dalam rangka mencapai sumber daya manusia yang demikian sangatlah penting untuk dilakukan pengembangan dan pelatihan Sumber Daya Manusia secara rutin. Pelatihan dan pengembangan Sumber Daya Manusia merupakan hal penting yang perlu dilakukan dalam sebuah organisasi dalam rangka meningkatkan kesejahteraan dan produktifitas Sumber Daya Manusia (Bryson, 2006: 211).

Pemustaka saat ini didominasi oleh generasi internet, generasi yang hidupnya tidak bisa lepas dari teknologi informasi. Generasi yang selalu menginginkan kemudahan dan kecepatan dalam melakukan segala kegiatan, termasuk dalam mendapatkan informasi. Generasi ini memiliki cara yang berbeda dalam memanfaatkan perpustakaan. Marc Prensky (2001) mengatakan generasi ini merupakan generasi yang menghabiskan hampir seluruh waktunya bersama dengan komputer, video games, digital music player, dan perangkat elektronik lainnya.

Menghadapi generasi yang seperti ini, pustakawan dituntut untuk mampu mengimbangi karakter dan gaya belajarnya. Pustakawan harus mampu mengembangkan potensi diri untuk bisa berinteraksi dan memahami kebutuhan generasi internet ini. Jika tidak, perpustakaan akan segera ditinggalkan karena generasi ini mungkin merasa tidak menemukan apa yang diharapkan di dalam perpustakaan. Pustakawan harus dibekali dengan perkembangan ilmu terkini sehingga mampu mengelola perpustakaan sesuai dengan kebutuhan pemustaka saat ini.

Secara seniortitas mulai tingkat kepangkatan dan jabatan kepustakawanan yang ada di perpustakaan universitas Hasanuddin dari hasil temuan sementara peneliti semuanya berada pada posisi yang ideal. Namun seniortitas, kepangkatan dan juga jabatan kepustakawanan yang ada tidak berkorelasi dengan kemampuan para pegawai dalam memberikan pelayanan sesuai dengan tingkat kebutuhan kepustakawanan saat ini. Dimana kebutuhan mendasar kepustakawanan saat ini adalah kemampuannya dalam bekerja menyesuaikan diri sesuai dengan era digitalisasi seperti sekarang ini.

Tuntutan ini sesuai juga dengan kebijakan akademik yang diberlakukan di universitas Hasanuddin sekarang ini dimana setiap karya tulisan mahasiswa termasuk juga dosen tidak lagi dalam bentuk hard copy tetapi harus dalam bentuk soft copy. Kondisi demikian yang kemudian menuntut intitusi perpustakaan yang ada di Universitas Hasanuddin melakukan pembenahan terkhusus kepada kemampuan para pegawai pada bagian digitalisasi

\section{METODE}

Penelitian ini dilaksanakan pada bulan Februari tahun 2021. Adapun lokasi penelitian ini dilakukan di Perpustakaan Universitas Hasanuddin. Penelitian ini menggunakan pendekatan deskriptif kualitatif. Data yang digunakan dalam penelitian ini adalah data primer dan data sekunder.

Teknik pengumpulan data dilakukan dengan metode observasi, wawancara, studi kepustakaan (Library Research), dan penelusuran data online. Teknik analisis data pada penelitian ini dilakukan secara cermat dimana data diseleksi mengggunakan teknik analisis data deskriptif yaitu data-data yang telah dihimpun dan dikumpulkan baik primer maupun sekunder, kemudian diambil kesimpulan sebagai jawaban masalah yang diteliti. Pengolahan data diakukan melalui reduksi data, penyajian data dan penarikan kesimpulan dan verifikasi data. Sementara itu kredibilitas data dalam penelitian ini dilakukan melalui perpanjangan pengamatan, meningkatkan ketekunan, triangulasi data, analisis kasus negatif, menggunakan bahan referensi, dan mengadakan member check.

\section{HASIL DAN PEMBAHASAN}

\section{Sistem Pengembangan Kepustakawanan}

Para pegawai di Perpustakaan Universitas Hasanuddin merupakan sumber daya manusia yang sangat penting dan berperan. Mereka bertugas untuk mengatur alokasi sumber daya untuk perkembangan keorganisasiannya, mampu menyajikan pelayanan kepada pengguna sepuas mungkin, mampu memenuhi seluruh sarana-prasarana dan perlengkapan yang diperlukan, dan memiliki kemampuan mengantisipasi berbagai gambaran dan imajinasi untuk perkembangan perpustakaan yang akan dicapai di masa mendatang. Dalam rangka mengukur sistem pengembangan kepustakawanan di perpustakaan Universitas Hasanuddin maka ada beberapa indikator yang dijadikan sebagai barometer pelaksanaan kerja-kerja pustakawan.

a. Pendidikan dan Pelatihan

Profesi pustakawan merupakan seseorang yang melaksanakan kegiatan pustakawan dengan jalan memberi layanan kepada masyarakat sesuai dengan tugas 
lembaga induknya berdasarkan ilmu perpustakaan dan dokumentasi serta informasi yang di milikinya melalui pendidikan dan pelatihan. Karena itu pendidikan dan pelatihan merupakan hal yang sangat penting dilakukan secara berkelanjutan dan terencana. Hasil wawancara peneliti dengan Kepala Perpustakaan Universitas Hasanuddin, Dr. Fierenzina G. Junus, M.Hum, kepada peneliti diungkapkan bahwa:

"Pendidikan dan pelatihan untuk SDM dilaksanakan dalam berbagai bentuk, lewat seminar, workshop, atau hanya sharing knowledge. Sharing knowledge (diskusi kecil) biasanya dilaksanakan oleh unit IT terutama jika ada aplikasi baru atau sistem baru yang diterapkan." (Wawancara, 8 Februari 2021).

Sementara itu, Ketua Unit Pengelolahan, bapak Dr. Iskandar, S.Sos., MM, kepada peneliti diungkapakan bahwa:

"Yang dilakukan UPT Perpustakaan dalam rangka pengembangan SDM adalah dengan melakukan: 1) Pelatihan sesuai dengan kebutuhan unit masing-masing. Misalnya untuk bagian pengolahan, melakukan pelatihan inlislite, pelatihan pengolahan buku; dan 2) Mengikutkan sertakan para pustakawan untuk mengikuti seminar, webinar, dan uji kompetensi, dan sertifikasi." (Wawancara, 9 Februari 2021)

Selain kegiatan pendidikan dan pelatihan yang dilakukan dalam rangka menunjang pengembangan SDM di Perpustakaan Universitas Hasanuddin, ada kegiatankagiatan lain yang cukup menarik bahkan menjadi terobosan dalam rangka upaya mendukung dan mendorong kemampuan para pustakawan di Universitas Hasanuddin.

Hasil wawancara peneliti dengan Ketua Unit Pengelolahan, bapak Dr. Iskandar, S.Sos., MM, kepada peneliti diungkapakan bahwa:

"Selain diklat, pengembangan SDM juga dilakukan dengan cara: mengikutkan lomba atau pemilihan pustakawan berprestasi (teladan), memberi bantuan penyelesaian studi bagi pustakawan yang lanjut studi, dan memberi bantuan biaya untuk penelitian tenaga fungsional yang lulus seleksi dalam kegiatan pengembangan profesi." (Wawancara, 9 Februari 2021)

Sementara itu, berbeda dengan apa yang disampaikan oleh kepala perpustakaan dalam hal metode. Dalam hal ini Kepala Perpustakaan Universitas Hasanuddin, Dr. Fierenzina G. Junus, M.Hum, kepada peneliti diungkapkan bahwa:

"Upaya lain adalah melakukan rotasi, seperti yang sudah dikatakan sebelumnya, melakukan pemindahan ini bertujuan agar pustakawan mempunyai pengetahuan dan keterampilan sebanyak mungkin mencakup bidang pekerjaan sebagai pustakawan." (Wawancara, 8 Februari 2021)

Dari pernyataan tersebut menjelaskan bahwa upaya peningkatan SDM yang selama ini dilakukan selain pendidikan dan pelatihan juga dilaksanakn dalam bentuk melakukan rotasi/ mutasi jabatan. Tujuannya selain penyegaran juga dalam upaya para pustakawan dapat dimungkinkan mendapatkan pengetahuan dan pengalaman yang baru dengan semua jenis pekerjaaan yang dikerjakan oleh seorang pustakawan.

b. Kegiatan Non Diklat

Salah satu bagian dalam rangka memperbaiki efektivitas dan efisiensi kerja dalam melaksanakan dan mencapai sasaran program-program kerja yang telah ditetapkan dalam sebuah organisasi adalah kegiatan non diklat. Perbaikan efektivitas dan efisiensi kerja melalui kegiatan non diklat dapat dicapai dengan meningkatkan pengetahuan, keterampilan, serta sikap terhadap tugastugas yang diemban.

Hasil wawancara peneliti dengan Kepala Perpustakaan Universitas Hasanuddin, Dr. Fierenzina G. Junus, M.Hum, kepada peneliti diungkapkan bahwa:

"Kegiatan non-diklat, juga kita lakukan dalam rangka meningkatkan SDM para pustakawan di perpustakaan Unhas. Kegiatan non diklat tersebut secara konkrit kita lakukan dalam bentuk rotasi pegawai di lingkungan perpustakaan." (Wawancara, 8 Februari 2021)

Sementara itu Ketua Unit Pengelolahan, bapak Dr. Iskandar, S.Sos., MM, kepada peneliti diungkapakan bahwa:

"Ya, kegiatan non diklat yang dilakukan untuk peningkatan SDM pustakawan meliputi kegiatan seminar, workshop baik secara luring maupun daring. Selain itu kita juga melakukan Focus Grup Diskusion (FGD) terkait pengembangan SDM dan penguasaan bidang tugas, serta mengikut sertakan pada kegiatan organisasi profesi IPI (Ikatan Pustakawan Indonesia)." (Wawancara, 9 Februari 2021)

Perpustakaan Universitas Hasanuddin sudah mengembangkan kerjasama dengan IPI sebagai suatu organisasi perpustakaan yang ada di Indonesia. Lembaga ini berperan sebagai lembaga profesi perpustakaan yang akan memberikan pengetahuan sekaitan dengan perkembangan ilmu kepustakawanan.

Walaupun beberapa pegawai pustakawan mengakui bahwa belum semuanya telah diikut sertakan dalam kegiatan non diklat yang diprogramkan oleh perpustakaan Universitas Hasanuddin namun pada dasarnya semua pustakawan diberi ruang dan kesempatan jika ingin mengembangkan kemampuannya. Hal ini disampaikan oleh Perpustakaan Unit Pengadaan, ibu Wahyuni Aras, A.Md, kepada peneliti mengungkapkan bahwa:

"Belum Pernah ada kegiatan tugas belajar yang diprogramkan perpustakaan, namun perpustakaan memberi peluang untuk para pustakawan untuk mengembangkan diri dengan pemberian ijin melanjutkan pendidikan.” (Wawancara, 10 Februari 2021)

\section{c. Tugas Belajar}

Dengan tingkat eskalasi kebutuhan suatu organisasi dalam hal ini suatu perpustakaan maka tindakan yang perlu dilakukan adalah memberikan ruang pelaksanaan terwujudnya kegiatan tugas belajar untuk memenuhi kebutuhan tenaga kerja terampil. Hal inilah yang kemudian disadari secara serius oleh para pustakawan yang ada di perpustakaan Universitas Hasanuddin. 
Hasil wawancara peneliti dengan Kepala Perpustakaan Universitas Hasanuddin, Dr. Fierenzina G. Junus, M.Hum, kepada peneliti diungkapkan bahwa:

"Tugas belajar diberikan bagi pustakawan lewat program yang dilaksanakan oleh pihak rektorat. Izin belajar pun demikian. Semua pustakawan dan tenaga pendidikan diberikan kesempatan yang sama." (Wawancara, 8 Februari 2021)

Jadi pemberian izin belajar merupakan hak yang sama semua pustakawanan dan perpustakaan Universitas Hasanuddin sebagai suatu lembaga penunjang pendidikan memberikan kesempatan yang sama kepada semua pegawainya untuk mengembangkan dirinya.

Sementara itu, Ketua Unit Pengelolahan, bapak Dr. Iskandar, S.Sos., MM, kepada peneliti diungkapakan bahwa:

"Untuk bagian pengolahan, belum ada yang ditugasbelajarkan karena staf bagian pengolahan rata-rata berpendidikan S1 Perpustakaan. Jadi sudah masuk kategori ahli." (Wawancara, 9 Februari 2021)

d. Promosi

Kepala Perpustakaan Universitas Hasanuddin, Dr. Fierenzina G. Junus, M.Hum, kepada peneliti diungkapkan bahwa:

"Promosi jabatan dilakukan secara berkala, dengan memperhatikan kompetensi para pustakawan." (Wawancara, 8 Februari 2021)

Sementara itu Ketua Unit Pengelolahan, bapak Dr. Iskandar, S.Sos., MM, kepada peneliti diungkapakan bahwa:

"Betul. Kemampuan SDM pustakawan juga dilakukan dengan promosi jabatan. Promosi jabatan bagi pustakawan yang dimaksud berupa kenaikan jabatan fungsional sesuai ketentuan dalam MenpanRB No. 9 Tahun 2014 tentang Jabatan Fungsional Pustakawan dan Angka Kreditnya." (Wawancara, 9 Februari 2021)

Dari pernyataan tersebut menggambarkan bahwa bahwa seharusnya dalam sebua lembaga perpustakaan salah satunya, kegiatan promosi jabatan tersebut harus dilakukan karena telah diatur didalam peraturan perundang-undangan yaitu melalui Kemenpan RB Nomor 9 Tahun 2014 tentang Jabatan Fungsional Pustakawan dan Angka Kreditnya.

Ketika peneliti melakukan konfirmasi dengan Ketua Unit Teknologi Informasi, bapak La Tommeng, S.Sos., M.I.Kom, kepada peneliti diungkapkan bahwa: (Wawancara, 10 Februari 2021)

"Promosi jabatan yang dilakukan merupakan kemampuan individu para pustakawan tersebut dapat memungkinkan peningkatan kinerja pustakawan yang lebih professional dan berkualitas, sehingga dapat memberikan pelayanan yang berkualitas pula terhadap pemakai (pengguna) perpustakaan Universitas Hasanuddin.” (Wawancara, 10 Februari 2021)

Sementara itu pengaruh promosi jabatan dalam meningkatkan kemampuan SDM di perpustakaan Universitas Hasanuddin, dalam hasil wawancara peneliti dengan Ketua Unit Pengelolahan, bapak Dr. Iskandar, S.Sos., MM, kepada peneliti diungkapakan bahwa: (Wawancara, 9 Februari 2021)

"Promosi jabatan tentu berpengaruh dalam meningkatkan kemampuan SDM di perpustakaan Unhas alasannya karena dengan kenaikan jabatan maka ada tantangan terhadap keberhasilan kerja dan pustakawan dapat proaktif untuk melakukan pekerjaan yang lebih tinggi tersebut karena memiliki amanah (jabatan)." (Wawancara, 9 Februari 2021)

Dengan adanya promosi jabatan pada umumnya merupakan suatu yang diharapkan oleh para pustakawan. Promosi jabatan ini pada dasarnya tujuannya untuk memotivasi para pustakawan untuk memberikan pelayanan dan performa terbaiknya. Sehingga dengan adanya promise jabatan tersebut para pustakawan akan semakin lebih semangat dalam bekerja.

\section{Hambatan dalam Pengembangan SDM Kepustakawanan}

a. Faktor Internal

1) Misi dan Tujuan Organisasi

Berdasarkan hasil penelitian peneliti dengan Ketua

Unit Pengelolahan, bapak Dr. Iskandar, S.Sos., MM, kepada peneliti diungkapakan bahwa:

"Kita memiliki misi yaitu mengikutkan pustakawan dalam kegiatan diklat pengembangan SDM. Namun sering terjadi hambatan dimana hambatan itu ada pada pemegang jabatan sendiri. Misalnya pustakawan yang telah diikutkan dalam diklat (pengembangan SDM), tetapi tidak berkreasi sendiri untuk mengasah (mengembangkan) ilmu yang diperolehnya tersebut maka tentu akan sia-sia. Selanjutnya adalah dukungan lembaga induk. Misalnya, Pustakawan sudah diikutkan diklat yang berhubungan dengan bidang tugas bagian pengolahan, tetapi tidak ditempatkan di bagian pengolahan. Intinya, the right man in the right place (orang yang benar ada ditempat yang benar)." (Wawancara, 9 Februari 2021)

Sementara itu, hasil wawancara peneliti dengan Kepala Perpustakaan Universitas Hasanuddin, Dr. Fierenzina G. Junus, M.Hum, kepada peneliti diungkapkan bahwa:

"Hambatan yang dialami biasanya adalah minat dan motivasi pustakawan dalam pengembangan dirinya yang masih kurang. Selain itu, hal lain yang juga menjadi hambatan adalah etos kerja yang juga masih sangat rendah pada beberapa SDM." (Wawancara, 8 Februari 2021)

Dari pernyataan tersebut diatas menjelaskan bahwa ada persoalan berkaitan dengan etos kerja para pustakawan. Etos kerja ini berkaitan dengan upayanya dalam mengambil inisiatif secara sendiri masih sangat rendah yang pada pokoknya akan berdampak baik bagi pengembangan perpustakaan sebagai salah lembaga pendidikan yang sangat penting peranannya.

2) Strategi Pencapaian Tujuan

Hasil wawancara peneliti dengan Kepala Perpustakaan Universitas Hasanuddin, Dr. Fierenzina G. Junus, M.Hum, kepada peneliti diuangkapkan bahwa: 
"Kita memiliki strategi dalam mengembangkan SDM pustakawan Universitas Hasanuddin. Salah satunya adalah pengikut sertaan pustakawan dalam kegiatankegiatan pengembangan diri." (Wawancara, 8 Februari 2021)

Tujuan dari strategi yang disebutkan diatas agar supaya strategi yang disusun dapat memperhitungkan dampak yang akan terjadi di dalam organisasinya. Secara tidak langsung hal ini dapat mempengaruhi pengembangan sumber daya menusia dalam organisasi.

3) Sifat dan Jenis Tujuan.

Sifat dan jenis kegiatan yang dilakukan di perpustakaan sangat penting dalam mengembangkan sumber daya manusia. Misalnya, suatu perpustakaan yang sebagian besar melaksanakan kegiatan teknis, akan berbeda dengan pola pengembangan sumber daya manusia pada perpustakaan yang bersifat ilmiah.

Hasil wawancara peneleliti dengan Hasil wawancara peneliti dengan Ketua Unit Pengelolahan, bapak Dr. Iskandar, S.Sos., MM, kepada peneliti diungkapakan bahwa:

"Sifat dan jenis tujuan yang kita buat di dalam kelembagaan di perputakaan Universitas Hasanuddin sangat berpengaruh dalam pengembangan para pustakawan. Secara kelembagaan kita membuat suatu kebijakan dimana sistem pengelolaan data-data penelitian oleh dosen dan dan mahasiswa tidak lagi dalam bentuk hard copy tetapi sudah dalam bentuk soff copy. Namun ini juga menjadi kendala bagi kami khususnya para pustakawan yang sudah terbiasa dengan pola lama." (Wawancara, 9 Februari 2021)

4) Jenis Teknologi yang Digunakan

Pengembangan perpustakaan diperlukan untuk mempersiapkan tenaga dalam mengoperasikan teknologi atau mungkin terjadinya otomatisasi kegiatan-kegiatan yang semula dilakukan secara manual oleh manusia. Hasil wawancara peneliti dengan Ketua Unit Teknologi Informasi, bapak La Tommeng, S.Sos., M.I.Kom, kepada peneliti diungkapkan bahwa:

"Penggunaan alat teknologi sebagai kebutuhan di masa perkembangan sekarang ini adalah juga menjadi konsen perhatian kami. Kami berupaya dengan segala daya yang kami miliki agar supaya perpustakaan Universitas Hasanuddin juga bisa menunjukkan prestasinya tanpa dibatasi dengan kebutuhan kemampuan pemahaman penggunaan teknologi bagi para pustakawan yang ada." (Wawancara, 10 Februari 2021)

Pekerjaan berbasis teknologi yang dipraktekkan di perpustakaan Universitas Hasanuddin sudah menjadi kebutuhan sekaligus keharusan bagi para pustakawan dalam bekerja. Hal ini sejalan dengan kebutuhan perkembangan teknologi yang sekarang ini menjadi suatu kebutuhan mendasar.

Hal yang sama juga diungkapkan oleh Perpustakaan Unit Pengadaan, ibu Wahyuni Aras, A.Md, kepada peneliti diungkapkan bahwa:

"Di perpustakaan kami tidak ada lagi pengimputan data dan informasi yang tidak berbasis teknologi. Jadi secara kita sudah memiliki aplikasi yang menghubungkan kita dengan server pusat dalam rangka melakukan penguploadan semua dokumen yang berkaitan dengan pekerjaan perpustakaan Universitas Hasanuddin." (Wawancara, 10 Februari 2021)

b. Faktor Eksternal

1) Kebijakan Pemerintah

Kebijakan-kebijakan pemerintah baik yang dikeluarkan melalui perundang-undangan, peraturan peraturan pemerintah, surat keputusan menteri maupun pejabat pemerintah merupakan arahan yang harus diperhitungkan oleh organisasi. Kebijakan-kebijakan tersebut akan mempengaruhi program program pengembangan sumber daya manusia dalam organisasi atau perpustakaan yang bersangkutan.

Hasil wawancara peneliti dengan Kepala Perpustakaan Universitas Hasanuddin, Dr. Fierenzina G. Junus, M.Hum, kepada peneliti diungkapkan bahwa:

"Hambatan dari luar yang kami alami dalam pengembangan kemampuan pustakawan salah satunya adalah tidak adanya beasiswa pendidikan lanjutan bagi tenaga pendidik untuk pustakawan yang bekerja di perpustakaan yang diberikan oleh institusi terkait." (Wawancara, 8 Februari 2021)

Sementara itu Ketua Unit Pengembangan SDM, bapak Andi Milu Manguna, S.Sos., MM, kepada peneliti diungkapkan bahwa:

"Hambatan yang mendasar yang kami alami dalam rangka pengembangan sumber daya pustakawan di pendidikan formal adalah keterbatasan secara financial untuk melanjutkan pendidikan atau ikut serta dalam pengembangan pendidikan pada lembaga yang ada kaitannya dengan pekerjaan pustakawanan." (Wawancara, 9 Februari 2021)

2) Sosio Budaya Masyarakat

Salah satu yang menjadi kendala dalam hal pengembangan pustakawan di Universitas Hasanuddin dalam hal kondisi sosio para pustakawan adalah etos kerja dan semangat berprestasi yang dimiliki oleh para pustakawan. Hasil wawancara peneliti dengan Kepala Perpustakaan Universitas Hasanuddin, Dr. Fierenzina G. Junus, M.Hum, kepada peneliti diungkapkan bahwa:

"Ada masalah yang cukup serius berkaitan dengan budaya organisasi yang juga kami alami di perpustakaan Universitas Hasanuddin. Masalah tersebut berkaitan dengan etos kerja dan semangat berprestasi yang dimiliki oleh para pustawakan masih sangat rendah." (Wawancara, 8 Februari 2021)

Selain masalah etos kerja dan semangat berprestasi yang masih sangat rendah, masalah lainnya adalah paradigma atau pandangan sebagian besar masyarakat terhadap pustakawan itu sendiri. Tidak sedikit orang memahami bahwa pustakawan itu tidak lebih sebatas sebagai penjaga rak buku. Sehingga ketika pemahaman ini berkembang maka kemudian berdampak kepada kreatifitas dan inovasi para pustakawan menjadi terbatas. 
Hasil wawancara peneliti dengan Ketua Unit Pengelolahan, bapak Dr. Iskandar, S.Sos., MM, kepada peneliti diungkapkan bahwa:

"Ada pemahaman yang keliru yang tidak sedikit para pustakawan yang membenarkannya, bahwa pustakawan itu adalah penjaga rak buku. Padahal dalam konteks kekinian pustakawan bukan lagi sebagai penjaga rak buku tetapi justru sudah menjadi lembaga penyedia informasi dan pengetahuan publik. Apalagi dizaman era digitalisasi seperti sekarang ini." (Wawancara, 9 Februari 2021)

Kondisi demikian tentu menjadi hambatan yang serius bagi suatu perpustakaan. Mengubah mindset atau paradigma para pustakawan, bahwa pustakawan itu bukan sekedar penjaga rak buku apalagi jika dihubungkan dengan posisi pustakawan di era perkembagan zaman seperti sekarang ini.

c) Perkembangan IPTEK

Sementara itu ada faktor lain yang menjadi hambatan dalam pengembangan SDM pustakawan salah satunya adalah kompetensi pustakawan layanan digital. Untuk mengelola layanan digital seorang pustakawan harus mempunyai pengetahuan dan keterampilan dalam layanan digital, diantaranya adalah kemampuan untuk mengoperasikan komputer dan internet.

Ketika peneliti melakukan wawancara kepada Ketua Unit Teknologi Informasi, bapak La Tommeng, S.Sos., M.I.Kom, kepada peneliti diungkapkan bahwa:

"Selama ini kita sudah melakukan sistem digitalisasi diperpustakaan Universitas Hasanuddin khususnya dalam hal penginputan hasil penelitian mahasiswa, dosen dan juga civitas akademika Universitas Hasanuddin. Jadi tidak ada lagi hasil penelitian-penelitian tersebut yang dikumpulkan dalam bentuk dokumen hard copy ke perpustakaan tetapi dalam bentuk soff copy. Sehingga hasil-hasil penelitian tersebut dapat diakses melalui internet." (Wawancara, 10 Februari 2021)

Sementara itu, wawancara dengan Kepala Perpustakaan Universitas Hasanuddin, Dr. Fierenzina G. Junus, M.Hum, alasan perubahan metode penyimpanan dokumen penelitian di perpustakaan Unversitas Hasanuddin yang sebelumnya menggunakan metode konvensional ke meotede elektronik, kepada peneliti diungkapkan bahwa:

"Salah satu pikiran maju yang kita lakukan adalah bagaimana menyesuaikan kemampuan pelayanan para pustakawan di perpustakaan Universitas Hasanuddin dengan kemajuan teknologi berbasis elektronik. Selain itu kita juga sudah menyadari bahwa secara kemampuan infrastrukur fisik, jika semua penelitian-penelitian yang dokumennya akan disimpan di perpustakaan dalam bentuk hard copy, kita tidak akan cukup tempat untuk menyimpan sehingga konsep penyimpanan data secara elektronik ini sangat membantu." (Wawancara, 8 Februari 2021)

Jadi dengan adanya penyimpanan yang dilakukan secara elektronik ini juga diharapkan memudahkan semua pihak untuk mengakses informasi yang berkaitan dengan penelitian di Universitas Hasanuddin. Segala informasi pengetahuan tersebut tidak perlu lagi harus mendatangi gedung perpustakaan tetapi melalui alat digital semua orang dapat mengaksesnya. Namun ada kendala yang kemudian ditemukan dalam hal pelaksanaan kebijakan digitalisasi tersebut. Hal ini terjadi dimana tidak semua pustakawan sudah memiliki kemampuan yang cukup untuk mengupload dokumen-dokumen tersebut berbasis elektronik.

Hasil wawancara peneliti dengan Ketua Unit Pengelolahan, bapak Dr. Iskandar, S.Sos., MM, kepada peneliti diungkapakan bahwa:

"Yang menjadi kendala selama ini dalam menjalakan program digitalasi perpustakaan adalah keterbatasan kemampuan SDM pustakawan dalam menjalankan aplikasi penguploadtan segala dokumen yang akan didokumentasikan di perpustaan Universitas Hasanuddin." (Wawancara, 9 Februari 2021)

Jadi persoalan yang kemudian muncul adalah belum semua pustakawan memiliki kemampuan dalam mengoperasikan sistem perpustakaan digitalisasi. Sekalipun selama ini para pustakawan di perpustakaan Universitas Hasanuddin secara tingkat ilmu pengetahuan disebut sebagai pustakawan ahli.

Organisasi tidak akan dapat berjalan sendiri dan mencapai tujuannya tanpa adanya Sumber Daya Manusia di dalamnya. Demikian halnya dengan perpustakaan, tanpa adanya pustakawan yang berkualitas, perpustakaan tidak akan mencapai tujuannya sebagai penyedia dan pengelola informasi. Perpustakaan, mungkin, akan tetap dianggap sebagai ruang untuk menyimpan tumpukan buku yang jarang dimanfaatkan karena terkalahkan dengan teknologi informasi yang mampu menyajikan informasi dengan cepat.

\section{Sistem Pengembangan Kepustakawanan}

Dalam sistem pelatihan yang dikembangkan di perpustakaan Universitas Hasanuddin adalah kegiatankegiatan pelatihan yang ada hubungannya dengan tugastugas para pustakawanan. Hanya kemudian yang menjadi masalah adalah bahwa diantara program-program pelatihan yang dicanangkan bahkan telah diikuti oleh para pustakawan kebanyakan lebih kepada urusan yang sifatnya formalistic belaka. Sehingga banyak-banyak pelatihan-pelatihan yang telah dilakukan tetapi hampir tidak memiliki korelasi dengan tingkat kebutuhan pekerjaan yang dikerjakan di perpustakaan Universitas Hasanuddin.

Menurut Mathis dan Jackson (2009, 301) bahwa pelatihan sebagai sebuah proses adalah tujuannya untuk mendapatkan kapabilitas untuk membantu pencapaian tujuan organisasional. Pelatihan memberikan karyawan pengetahuan dan keterampilan yang spesifik dan dapat diidentifikasi untuk digunakan dalam pekerjaannya.

Jika mengacuh kepada pendapat tersebut diatas maka seharusnya suatu pelatihan yang dikembang dalam suatu organisasi harus berorientasi kepada tujuan yang 
diharapkan kegiatan pelatihan tersebut dilakukan. Karena jika keluar dari itu maka sesunggunya pelatihan yang dilakukan tersebut menjadi tidak berarti dan cenderung sebagai kegiatan yang mubasir saja.

Sementara itu berdasarkan Peraturan Pemerintah (PP) Nomor 101 Tahun 2000 tentang Pendidikan dan Pelatihan (Diklat) Jabatan Pegawai Negeri Sipil tujuan Diklat adalah salah satunya adalah untuk meningkatkan pengetahuan, keahlian, keterampilan, dan sikap untuk dapat melaksanakan tugas jabatan secara profesional dengan dilandasi kepribadian dan etika PNS sesuai dengan kebutuhan instansi. Artinya bahwa seharusnya suatu diklat yang dilakukan tersebut harus bermanfaat sebagai solusi atau soluktif dalam setiap pekerjaan.

M.J. Tesin dalam Gaol (2014) memberikan penjelasan tentang pentingnya pelatihan dan pengembangan, yaitu adanya pengembangan dan pelatihan akan membantu individu tersebut untuk mampu membuat keputusan dan pemecahan masalah denghan lebih baik lagi. Mempertinggi rasa percaya diri dan pengembangan diri. Membantu mengurangi rasa takut dalam menghadapi tugas baru. Kemampuan ini sangatlah dibutuhkan oleh pustakawan yang mengelola perpustakaan yang memiliki pemustaka yang didominasi oleh generasi internet. Banyak tugas baru yang harus dilaksanakan sebagai upaya mengimbangi kebutuhan pemustaka di era internet ini.

Pada umumnya organisasi melakukan program pelatihan karena adanya faktor perubahan kebijakan, sistem, alat, dan teknologi baru, ditemukannya kemampuan kerja karyawan yang di bawah standar, adanya rencana pengembangan karyawan tertentu untuk mengembang posisi tertentu, dan dengan adanya karyawan baru. Di perpustakaan Universitas Hasanuddin sendiri ada kebijakan baru dimana setiap hasil penelitian civitas akademika proses pendokumentasiannya dilakukan dalam bentuk elektronik, jadi tidak ada lagi dalam bentuk konvensional.

Langkah organisasi untuk melakukan pengembangan ini tentunya butuh dukungan dari berbagai pihak termasuk dari individu itu sendiri. Motivasi dan apresiasi akan menentukan keinginan Sumber Daya Manusia untuk melakukan pengembangan sesuai dengan program organisasi. Aturan dan manajemen untuk pengembangan juga harus dipersiapkan dengan maksimal agar supaya Sumber Daya Manusia yang mengikuti program pengembangan ini juga dapat bekerja secara maksimal dan dapat memberikan hasil yang maksimal pula. Reward dan punishment juga harus disiapkan dan dikomunikasikan dengan jelas.

Salah satu reward yang sangat penting dalam memotivasi karyawan dalam sebuah perpustakaan adalah pemberian promosi jabatan. Namun dalam prakteknya promosi jabatan di perpustakaan Universitas Hasanuddin belum dilakukan sebagaimana seharusnya. Artinya bahwa selama belum ada pustakawan yang secara langsung diberikan jabatan atau posisi yang lebih baik karena berprestasi di perpustakaan.
Berdasarkan hasil temuan peneliti bahwa selama ini promosi jabatan untuk para pustakawan yang berprestasi belum dilakukan dengan baik. Sekalipun promosi jabatan bagi pustakawan yang dimaksud berupa kenaikan jabatan fungsional sesuai dengan ketentuan dalam Menpan RB No. 9 Tahun 2014 tentang Jabatan Fungsional Pustakawan dan Angka Kreditnya. Sementara disisi yang lain promosi jabatan ini penting karena berpengaruh dalam meningkatkan kemampuan SDM di perpustakaan Universitas Hasanuddin. Hal tersebut didasarkan kepada alasannya bahwa dengan kenaikan jabatan maka ada tantangan terhadap keberhasilan kerja dan pustakawan dapat proaktif untuk melakukan pekerjaan yang lebih tinggi tersebut karena diberi amanah (jabatan).

Sementara beberapa hal lain yang juga dilakukan dilakukan di perpustakaan Universitas Hasanuddin yaitu mengikut sertakan para pustakawan pada berbagai ajang lomba dan kompetensi untuk menguji sejauh mana kompetensi pustawakan, memberi kesempatan seluasluasnya untuk mengikuti berbagai macam seminar, workshop, diklat, bukan hanya dibidang perpustakaan saja tetapi juga bidang lainnya seperti Leadership, Marketing, Communication. Semua ilmu ini sangatlah dibutuhkan oleh pustakawan dalam mengembangkan perpustakaannya.

Hambatan dalam Pengembangan SDM Kepustakawanan

Seperti yang telah dibahas sebelumnya bahwa Sumber Daya Manusia memegang peranan penting dalam hidup organisasi. Sumber Daya Manusia yang berkualitas tentu perlu untuk dipertahankan agar supaya tetap dapat berkarya dalam organisasi. Namun salah satu hal yang sering menjadi masalah adalah adanya hambatanhambatan dalam mengembangkan kemampuan SDM para pustakawan.

Berdasarkan pada Undang-Undang Nomor 43 Tahun 2007 tentang perpustakaan pasal 1 ayat 8 dinyatakan bahwa pustakawan adalah seseorang yang memiliki kompetensi yang diperoleh melalui pendidikan atau pelatihan kepustakawanan serta mempunyai tugas dan tanggung jawab untuk melaksanakan pengelolaan dan pelayanan perpustakaan.

Sementara itu Ikatan Pustakawan Indonesia menyatakan pustakawan adalah orang yang memberikan dan melaksanakan kegiatan perpustakaan dalam usaha pemberian, pelayanan jasa kepada masyarakat sesuai dengan misi yang diemban oleh badan induknya berdasarkan ilmu perpustakaan, dokumentasi dan informasi yang diperolehnya melalui pendidikannya.

Namun masalahnya kemudian adalah banyak pustakawan yang tidak dapat memberikan perannya dengan baik. Hal ini dikarenakan adanya paradigma yang salah terhadap para pustakawan yang selama ini dianggap sebagai penjaga rak buku. Dengan adanya kemajuan teknologi di era digitalisasi seperti sekarang ini para pustakawan dituntut untuk memiliki kemampuan dalam rangka mengoperasikan sistem elektronik berbasis digitalisasi dalam menyimpan dan menyebarluaskan 
segala informasi pengetahuan yang dimiliki oleh perpustakaan.

Sementara itu Menurut Nanan Khasanah dalam Syahrir (2009:5), ciri-ciri kompetensi salah satunya yaitu kompetensi profesional yaitu yang terkait dengan pengetahuan pustakawan di bidang sumber-sumber informasi, manajemen dan penelitian, dan kemampuan menggunakan pengetahuan tersebut sebagai dasar untuk menyediakan layanan perpustakaan dan informasi.

Dari terori tersebut diatas menggambarkan bahwa betapa para pustakawan di masa-masa sekarang ini harus dibekali dengan kemampuan-kemampuan khusus sesuai dengan tingkat kebutuhan ilmu pengetahuan dan teknologi di era digitalisasi seperti sekarang ini. Kita mengakui bersama bahwa perkembangan ilmu pengetahuan dan teknologi di luar organisasi, dewasa ini telah sedemikian pesatnya. Organisasi yang baik harus mengikuti arus tersebut dan harus mampu memilih teknologi yang tepat. Oleh karena itu, kemampuan pegawai harus diadaptasikan dengan kondisi tersebut.

Diperpustakaan Universitas Hasanuddin sendiri telah memprogramkan sistem electronick perpustakaan (e-perpustakaan). Langka ini diambil sebagai bagian dari komitmen perpustakaan Universitas Hasanuddin untuk terus meningkatkan kualitas pelayanan yang diberikan. Hanya yang kemudian menjadi hambatan adalah tidak semua pustakawan telah dibekali untuk mengoperasikan sistem penyimpanan dan penyebaran informasi berbasis elektronik.

\section{KESIMPULAN DAN SARAN}

Sistem pengembangan sumber daya manusia di perpustakaan Universitas Hasanuddin dilakukan melalui pendidikan dan pelatihan (diklat) dilakukan dengan berbagai bentuk kegiatan, seperti seminar, webinar, workshop atau sharing knowledge (diskusi kecil) uji kompetensi, dan sertifikasi. Sementara itu kegiatan non diklat dilakukan melalui tugas belajar dan promosi jabatan. Faktor penghambat dalam pengembangan SDM di perpustakaan Universitas Hasanuddin secara internal maupun eksternal yaitu sikap dan etos kerja para pustakawan yang cenderung abai dan perlu upaya mengembangkan keterampilan yang dimilikinya dalam pengelolaan perpustakaan berbasis electronic perpustakaan (e-perpustakaan).

Sistem pengembangan kepustakawanan di Perpustakaan Universitas Hasanuddin seharusnya dilakukan secara konsisten bukan hanya melalui pendidikan dan pelatihan serta kegiatan non-diklat tetapi juga yang mesti harus dilakukan adalah pengembangan kepustakawanan melalui tugas belajar dan juga promosi jabatan untuk pustakawanan yang berprestasi.

\section{DAFTAR PUSTAKA}

Anwar Prabu Mangkunegara. 2003. Perencanaan dan Pengembangan Sumber Daya Manusia. Bandung. Refika Aditama.

Depdikbud. 2004. Pedoman Perpustakaan Perguruan Tinggi. Jakarta. Departemen Pendidikan dan Kebudayaan.

Hadari Nawawi. 2012. Metode Penelitian Bidang Sosial. Yogyakarta. Universitas Gajah Mada.

Miftah Thoha. 2005. Kepemimpinan Dalam Manajemen. Jakarta. PT. Raja Grafindo Persada.

Nugrahani. 2012. Pengaruh Ukuran Perusahaan, Likuiditas, Profitibiitas, dan Risiko Bisnis Terhadap Struktur Modal pada Perusahaan Farmasi. Jakarta. Graha Media.

Soekidjo Notoatmodjo. 2003. Pendidikan dan Perilaku Kesehatan. Jakarta. PT. Rineka Cipta.

Sulistyo-Basuki. 2006. Metode Penelitian. Jakarta. Wedatama.

Susilo Martoyo. 2000. Manajemen Sumber Daya Manusia. Yogyakarta. Penerbit BPFE.

Undang-Undang Republik Indonesia Nomor 20 Tahun 2003 Tentang Sistem Pendidikan Nasional.

Undang-Undang nomor 43 tahun 2007 tentang Tujuan Perpustakaan

Undang-Undang Nomor 43 Tahun 2007 tentang Perpustakaan.

Peraturan Pemerintah (PP) Nomor 101 Tahun 2000 tentang Pendidikan dan Pelatihan (Diklat) Jabatan Pegawai Negeri Sipil. 